\title{
Locally Driven Options for Managing Sanitation Issues in Kalingalinga Township of Lusaka
}

\author{
Kabwe H. Mubanga, Fiona C. Mubanga, Beatrice Chirwa, Annie Musonda-Mubanga, \\ and Rebecca Kayumba
}

\section{ABSTRACT}

In recent years, the challenge of sanitation has manifested itself in the perennial outbreaks of diseases such as cholera and dysentery, as well as pollution of water resources, contamination of air, soil and land proliferation of pests and vermin and the loss of aesthetic beauty particularly in low income residential areas. These areas are densely populated implying that externalities resulting from unsanitary conditions will impact more people compared to high residential areas. Further, as long as sanitation management solutions introduced to the locals do not seem to be locally driven, promoters are likely to face dis-adoptions. This study aimed at investigating locally driven options for managing sanitation issues in Kalingalinga Township. It utilized 126 respondents who were systematically randomly sampled. Data analysis was conducted using descriptive statistics, correlation techniques and the least square difference (LSD) methods. The study identified sanitation issues related to waste disposal, unsanitary toilets, intermittent water supply and flooding due to blocked drainages during the rainy season as key sanitation issues affecting residents of Kalingalinga Township. The ratings of the sanitary conditions in the area were largely influenced by one's level of education and exposure with respondents who had undergone higher levels of formal education being more stringent in their ratings. While level of income was a determinant of access to water supply in the Township, the residents' poor attitude towards solid waste disposal was a major challenge contributing to unsanitary conditions in the area. The study identified the need to separate generated waste into usable categories that could be recycled, reused, and sold as raw materials to particular manufacturing industries. The success of locally driven options would hinge on residents being educated on the sustainable waste management techniques which would also contribute to household income generation through selling off usable wastes. Further, a change in the attitude of residents towards waste management, use of designated solid waste collectors who take waste to designated dump sites, use of disinfectants in toilets and avoidance of stagnating waste water would also help to manage sanitation in the area. Poor sanitation and hygiene have contributed to malnutrition cases in Zambia which may be caused by diarrheal diseases. If sanitation is well managed in this Township, then diarrheal cases, caused by poor sanitation, can be minimized. While the Lusaka City Council was often mentioned as a major solution towards waste management in the area, the study recommended participatory education of the locals in sustainable waste management, conversion of household waste into household income and a change in residents' attitude as the starting points in ensuring successful sanitation management.

Keywords: drainage, peri-urban areas, sanitation facilities, solid waste.
Published Online: February 25, 2022

ISSN: $2684-446 \mathrm{X}$

DOI :10.24018/ejgeo.2022.3.1.248

Kabwe H. Mubanga*

Department of Geography and Environmental Studies, University of Zambia, Zambia.

(e-mail: kabwe.mubanga@1ive.com)

Fiona C. Mubanga

Department of Geography and Environmental Studies, University of Zambia, Zambia.

(e-mail: chisanga22@gmail.com)

Beatrice Chirwa

Department of Sociology and Psychology, School of Education, Chalimbana University, Private Bag E1, Chongwe, Zambia.

(e-mail: bchirwa1962@yahoo.com)

Annie Musonda-Mubanga

Department of Leadership and Governance, School of Leadership and Business Management, Chalimbana University, Private Bag E1, Chongwe, Zambia.

(e-mail: mubanga.am@gmail.com)

Rebecca Kayumba

Department of Home Economics and Food Science, Chalimbana University, Private Bag E1, Chongwe, Zambia.

(e-mail: rkayumbapiyo@gmail.com)

*Corresponding Author

\section{INTRODUCTION}

Sanitation is the provision of adequate infrastructure and services for the safe disposal of human waste [1]. It also applies to the maintenance of hygienic conditions, through services such as garbage and waste disposal which entails setting up measures necessary for improving and protecting the health and well-being of the people [2]. The World Health
Organization [1] describes adequate, accessible, and acceptable basic sanitation as one of the major global issues requiring immediate attention. Developing countries have grappled with access to adequate sanitation for centuries. Minh and Hung [3] estimated that as of 2006, there were 2.6 billion people worldwide who did not have access to adequate sanitation. Of this number, 5\% were from sub-Saharan Africa. Evidently, researchers have shown that lack of adequate sanitation is also a challenge even in Zambia [2], 
[4].

The Rapid Assessment of Sanitation Status in Lusaka that was conducted by Lusaka Water and Sewerage Company, revealed that on-site sanitation facilities were used by $90 \%$ of households in Lusaka. Of this $90 \%, 50 \%$ used improved pit latrines, $22 \%$ used septic tanks, $10 \%$ used pour flush latrines and $8 \%$ used traditional latrines. Only $9 \%$ are connected to a LWSC sewer line and $1 \%$ did not have access to sanitation facilities [4].

There are several efforts being made to improve sanitation for residents of Lusaka City. One of the major efforts is the Lusaka Sanitation Programme (LSP) which is spearheaded by the LWSC with technical and financial support from various global organizations. The program is governed by three main strategies which are centered on: (i) upgrading and expanding sewerage networks to select neighbourhoods; (ii) developing on-site sanitation facilities and services in peri-urban areas; (iii) strengthening the capacity of LWSC [5]. Apart from services that are directly related to the disposal of human waste, other factors such as erratic water supply, poor drainage and inadequate waste collection systems have an impact on sanitation, especially in Lusaka's peri-urban areas. Between 2000 and 2010, the Zambian government and cooperating partners made some progress toward improving water supply to Lusaka's peri-urban areas. For example, a study by Mweembe [6] revealed that Care International in 2010 collaborated with LWSC and Ward Development Committees (WDCs) in putting up tap stands in peri-urban areas for the general public to access water. These taps are currently being manned by the Water Trusts in the various communities.

Lusaka's limestone bedrock poses an inherent challenge to the natural drainage of storm water. This is especially apparent in peri-urban areas were roads have no side drains and pit latrines are used by $95 \%$ of the residents [5]. The Zambian government with funding from the Millennium Challenge Cooperation (MCC) has constructed drainages in some areas of Lusaka. Regarding solid waste management, the Lusaka City Council (LCC) has partnered with various Community Based Enterprises (CBEs) to increase their capacity to collect solid waste in Lusaka City [7].

Sanitation and nutrition are closely related in the sense that; when sanitation is absent, diarrheal cases can compromise the normal growth of children especially up to the age of 24 months (1,000 days from conception). Hence the first 1,000 days spanning conception to age 24 months have been dubbed the 'critical window' for prevention and action [8]. This means that more care in terms of sanitation and feeding is required during the period of conception to the second birthday of an infant to make sure that nutrients are absorbed and retained in the body for optimum health, growth, and neurodevelopment across the lifespan. Diarrhoea, often caused by poor sanitation, lack of hygiene, and unsafe drinking water can inhibit nutrient absorption and negatively impact physical and cognitive development [9].

Stunted growth is a reduced growth rate in human development and is a primary manifestation of malnutrition in early childhood. Undernutrition accounts for more than one third of child deaths around the world. Generally, when people are undernourished, they have low resistance to infection and are more likely to die from diarrheal diseases and respiratory infections. Frequent illness also saps the nutritional status of those who survive, locking them into a vicious cycle of recurring sickness [10].

There is emerging evidence of another intestinal disease, environmental enteropathy, which has an effect on child growth. Environmental enteropathy is a disease of the small intestine that results from chronic childhood exposure to faecal microbes and poor sanitation [11]. Reductions in diarrheal disease alone through safe sanitation can prevent long- term morbidity and child deaths caused by undernutrition. Children living in households with proper sanitation and hygiene are taller for their age, or less stunted, compared to children living in unsafe environments [12][14].

Most of the interventions regarding sanitation have either been done at legislature level or have been donor-funded in which case they have been donor driven and not necessarily, locally driven. For sanitation projects that have been sponsored through organizations such as the LWSC or the LCC, a lack of planning for project sustainability beyond the period of funding has usually resulted in the recorded successes during the period of the project to be regressed once the funding stops. As a result, benefits which usually accrue to the locals from such sanitation projects only last as long as the project receives funding. The major loopholes in such projects have been a failure to sustain the project outcomes as they are not locally driven in the first place. Therefore, this study was aimed at exploring locally driven options for managing sanitation problems in Lusaka's Kalingalinga Township. The study further assessed the residents' satisfaction of the sanitary conditions by examining their perceptions of the existing sanitation situation in the township. Specific objectives for the study where threefold: (i) to find out the sanitation issues affecting Kalingalinga Township. (ii) to assess the available options for managing sanitation issues in Kalingalinga, Compund and (iii) to establish sustainable locally driven options for managing sanitation issues in Kalingalinga Township.

\section{Methodology}

\section{A. Description of the Study Area}

Kalingalinga Township is located $9 \mathrm{~km}$ east of Lusaka's Central Business District at GPS coordinates $15^{\circ} 25^{\prime} 0^{\prime \prime} \mathrm{S}$ $28^{\circ} 17^{\prime} 0^{\prime \prime} \mathrm{E}$. The township has 8,356 households accommodating 39, 139 residents of which 18, 945 are males and 20, 194 are females. The township is informal and commonly classified among peri-urban areas in the local government's context [5]. The Township is densely populated and characterized by poor housing units and unsanitary toilets, high unemployment levels and poverty [6] Basic services such as water, sewer, storm water drainage and solid waste disposal are inadequate [4].

The township experiences climatic conditions that are typical of Lusaka District. There are predominantly three seasons in a year, namely, warm-wet season, cold-dry season and warm-dry season. The coldest month is July, with temperatures reaching a mean lowest of $7{ }^{\circ} \mathrm{C}$ while the hottest month is October, with a mean highest temperature of $35^{\circ} \mathrm{C}$. The area receives an annual mean rainfall of between $800 \mathrm{~mm}$ 
to $1000 \mathrm{~mm}$. The township is largely residential, although most of its road frontage on the eastern and northern boundaries has been converted to commercial use in the recent past.

\section{B. Sampling}

The research design used in this study was exploratory in nature. Explorative research is one which gives new explanations, theories, and hypotheses to reality with the aim of offering a new perspective to how a particular phenomenon works. Exploratory research may also provide new perspectives of how or in what way different factors relate to each other, even casually. An exploratory design was appropriate for this research because it sought out locally driven sanitation options and provided satisfaction ratings of the facilities while comparing these ratings to factors such as level of education.

Systematic random sampling was used to select the participant households for this research. Systematic sampling is a method of sampling by which the first unit of sampling is selected at random, and the remaining units are selected according to a predetermined pattern [15]. In this research, systematic sampling with a sampling unit of 10 was used to enable the researcher to cover a greater spatial extent of the different elements within Kalingalinga Township. The total sample size for the study was 126 which comprised 48 males and 78 females.

\section{Data Collection}

Data collected for this research included primary data and field observations. A semi-structured interview guide was used to collect primary data from the 126 participants that were sampled to take part in this study. Observations of sanitation facilities such as toilets, domestic solid waste disposal facilities and drains were made.

\section{Data Analysis}

Primary data was analyzed qualitatively and quantitatively. The Chi-Square test was used to rate sanitation conditions in Kalingalinga based on level of education of the respondents and the respondents' length of stay in the township. The Least Square Difference (LSD) method was used to make pair wise comparisons among different classes of residents and their daily water access. The classes were determined based on the daily hours of water access. Analysis involving household income levels and daily hours of water access were done using Pearson Correlation Coefficient. Characterizing demographic factors and the distribution trends of sanitation options and sanitation issues in the Township were done using descriptive statistics. Duration of daily water supply and how water supply was rated by the respondents, as well as methods of water treatment and waste disposal were also presented using descriptive statistics.

\section{RESULTS}

\section{A. Demographic Characteristics}

The sample was made up of the majority of respondents who had stayed in Kalingalinga Township for longer than 10 years (Table I). Of the 43 who had been in this area for less than 10 years, only 14 had been there for two years or less.
The sample even included residents who had been in the area for over half a century. The inclusion of such residents was necessary as they provided a historical perspective of the sanitary changes that had occurred to the area, as well as the change in solid waste management over time. Further, none of the sampled respondents were illiterate, as they had all attained some levels of education which ranged from Grade 4 at Primary level to University level. Few respondents (13) were employed in the public sector, and only a few (5) were unemployed. The rest were either managing their own businesses or were employed in the private sector. Most of the respondents for this study were women (78) who were nearly twice the men interviewed (48). The seemingly gender imbalance was despite the sampling happening at household level. There were more women found at households than men during the period of interview which contributed to more women being interviewed. However, this did not affect the results of the study as the women were able to respond to the researchers' questions and were able to provide the information sought.

TABLE I: DEMOGRAPHIC CHARACTERISTICS OF SAMPLED RESPONDENTS IN

\begin{tabular}{|c|c|c|c|}
\hline \multicolumn{4}{|c|}{ KALINGALINGA TOWNSHIP } \\
\hline & Frequency & Education Level & Frequency \\
\hline \multicolumn{4}{|l|}{ Gender } \\
\hline Male & 48 & Grade 4 & 7 \\
\hline Female & 78 & Grade 5 & 6 \\
\hline Occupation & & Grade 6 & 8 \\
\hline $\begin{array}{l}\text { Own } \\
\text { Business }\end{array}$ & 48 & Grade 7 & 12 \\
\hline Taxi Driver & 11 & Grade 8 & 11 \\
\hline $\begin{array}{l}\text { Casual } \\
\text { Work }\end{array}$ & 17 & Grade 9 & 30 \\
\hline $\begin{array}{l}\text { Government } \\
\text { employed }\end{array}$ & 13 & Grade 10 & 9 \\
\hline Unemployed & 5 & Grade 11 & 8 \\
\hline Farmer & 3 & Grade 12 & 31 \\
\hline Hair stylist & 14 & College & 2 \\
\hline Housewife & 15 & University & 2 \\
\hline Marital Status & & Length of stay & \\
\hline Single & 29 & $\leq 10$ & 43 \\
\hline Married & 69 & $11-20$ & 35 \\
\hline Widow & 19 & $21-30$ & 23 \\
\hline Divorced & 9 & $31-40$ & 17 \\
\hline Age & & $41-50$ & 5 \\
\hline$\leq 20$ & 3 & $\geq 51$ & 3 \\
\hline $21-25$ & 12 & & \\
\hline $26-30$ & 14 & & \\
\hline $31-35$ & 20 & & \\
\hline $36-40$ & 21 & & \\
\hline $41-45$ & 16 & & \\
\hline $46-50$ & 12 & & \\
\hline$\geq 51$ & 28 & & \\
\hline
\end{tabular}

\section{B. Sanitation Issues Affecting Residents of Kalingalinga Township}

Poor drainage systems in Kalingalinga Township were looked at as the major sanitation issue facing residents (Fig. 1). Poor waste disposal, unsanitary toilets as well as erratic water supply were also seen as big sanitary issues in the Township.

While few residents considered floods and diseases as major sanitary issues, their influx and increase is related to the major sanitary issues. For example, poor waste disposal, poor drainage systems, erratic water supply and poor conditions of toilets are either causes or catalysts of disease 
in the township. Floods are also exacerbated by poor drainage systems in the Township.

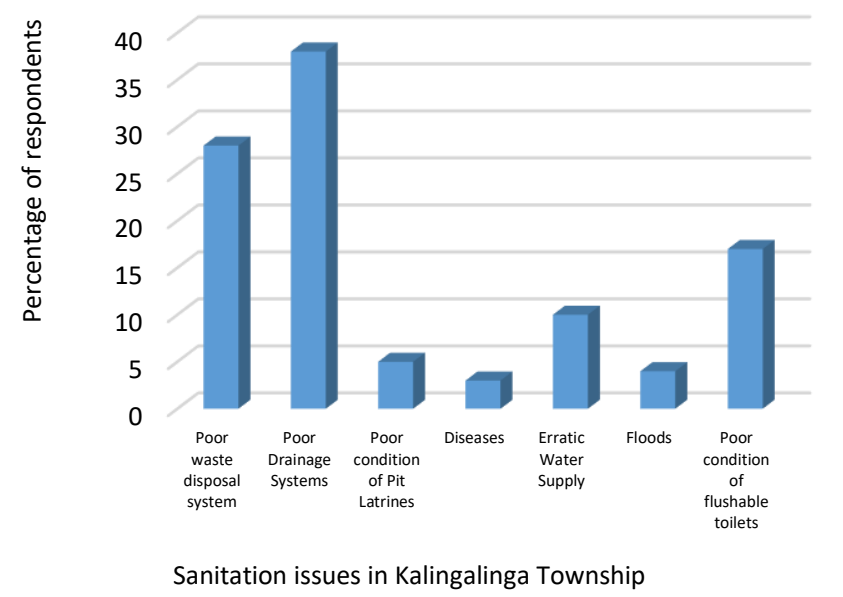

Fig. 1. Major sanitation challenges faced by residents of Kalingalinga Township.

\section{Sanitation Issues in Toilets}

Since flushable toilets and pit latrines were identified as major sanitary issues in Kalingalinga Township, extent of their use. Most households had both flushable toilets and pit latrines with $62 \%$ admitting to using the pit latrines more than the flushable toilets (Fig. 2).
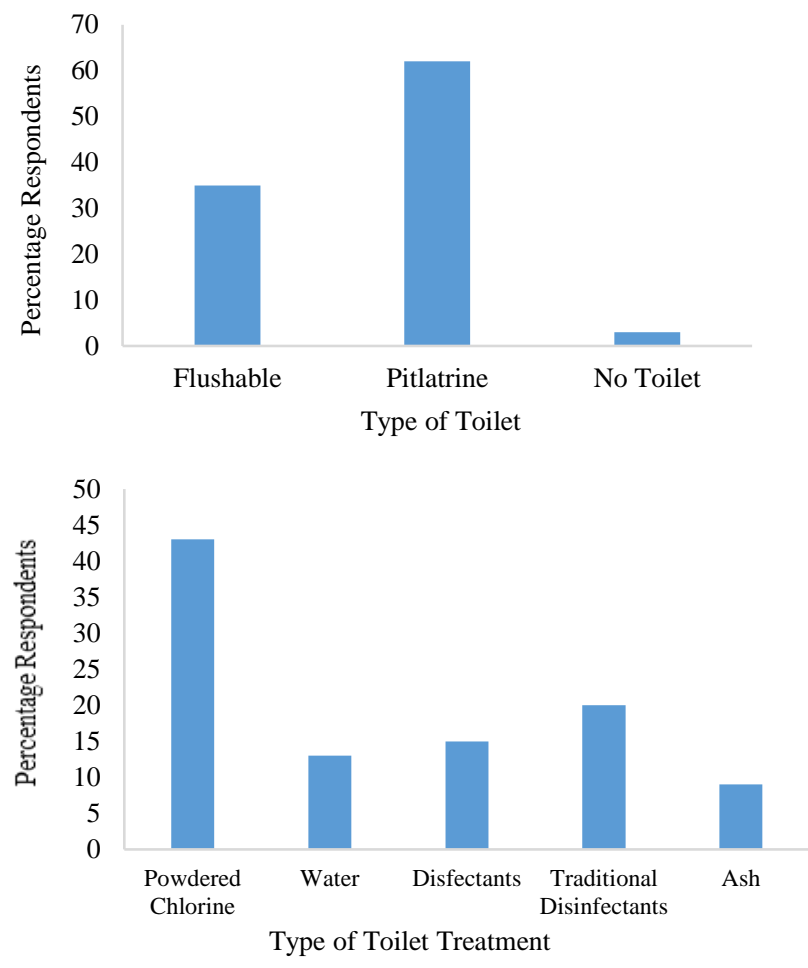

Fig. 2. Percentage of respondents who use particular toilets in Kalingalinga Township and the methods of toilet treatment utilized.

The study also revealed a $3 \%$ of respondents whose households had no toilet and residents were largely dependent on neighbors' toilets. The use of powdered chlorine (43\%) was the most common method of disinfecting toilets among Kalingalinga residents. Traditional disinfectants such as use of pawpaw (Carica papaya) leaves $(20 \%)$ was also a common practice. However, there was a $13 \%$ of residents who only depended on water for cleaning toilets with no disinfectants applied. However, the water situation in the Township was said to be erratic (Fig. 1) which made it a challenge to maintain cleanness in toilets. Majority of the residents received less than 10 hours of water in a day (Fig. 3a). Since issues of sanitation are closely related to availability of water, this was a source of concern. However, there were some residents who had very high access to water with between 21 24 hours of water daily, albeit a few (10\%) (Fig. 3b).
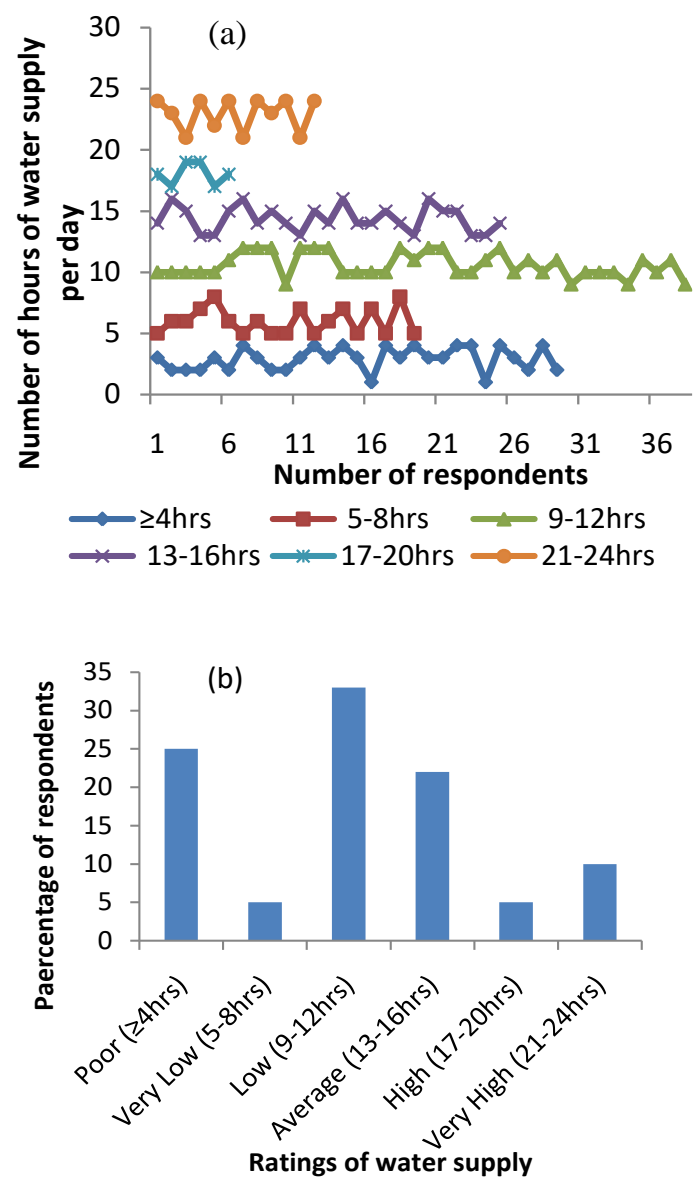

Fig. 3. Graphs showing (a) Number of hours of water supply available to different households in Kalingalinga Township (b) Rating the levels of access to water supply by residents of Kalingalinga Township based on the number of hours of water access per day

Kalingalinga Township had $63 \%$ of its residents with not more than 12 hours of daily access to domestic water supply, of which $25 \%$ had only 4 hours or less access to water. Such high levels of erratic water supply could have contributed to the reduced sanitation levels observed in the area. Residents who had between 21-24 hours of daily water supply had their own boreholes or shallow wells installed within their premises.

There were significant differences in the number of residents in Kalingalinga found in each category of water accessibility ( $\mathrm{F}=871.409 ; \mathrm{P}=0.001$ ) (Table II). While many were in the low access, average and poor access to water category, very few had high and very high access to water (Fig. 3). 
TABLE II: DEMOGRAPHIC CHARACTERISTICS OF SAMPLED RESPONDENTS IN KALINGALINGA TOWNSHIP

\begin{tabular}{|c|c|c|c|c|}
\hline Class & Class & $\begin{array}{c}\text { Mean } \\
\text { Difference }\end{array}$ & Std. Error & Sig. \\
\hline \multirow[t]{5}{*}{ Poor } & Very Low & $-3.10^{* 0}$ & 0.304 & 0.000 \\
\hline & Low & $-7.71^{*}$ & 0.254 & 0.000 \\
\hline & Average & $-11.46^{*}$ & 0.281 & 0.000 \\
\hline & High & $-15.10^{*}$ & 0.462 & 0.000 \\
\hline & Very High & $-20.02^{*}$ & 0.353 & 0.000 \\
\hline Very & Poor & $3.10^{*}$ & 0.304 & 0.000 \\
\hline \multirow[t]{4}{*}{ Low } & Low & $-4.61^{*}$ & 0.289 & 0.000 \\
\hline & Average & $-8.36^{*}$ & 0.313 & 0.000 \\
\hline & High & $-12.00^{*}$ & 0.482 & 0.000 \\
\hline & Very High & $-16.92^{*}$ & 0.380 & 0.000 \\
\hline \multirow[t]{5}{*}{ Low } & Poor & $7.71^{*}$ & 0.254 & 0.000 \\
\hline & Very Low & $4.61^{*}$ & 0.289 & 0.000 \\
\hline & Average & $-3.75^{*}$ & 0.265 & 0.000 \\
\hline & High & $-7.39^{*}$ & 0.452 & 0.000 \\
\hline & Very High & $-12.31^{*}$ & 0.341 & 0.000 \\
\hline \multirow[t]{5}{*}{ Average } & Poor & $11.46^{*}$ & 0.281 & 0.000 \\
\hline & Very Low & $8.36^{*}$ & 0.313 & 0.000 \\
\hline & Low & $3.75^{*}$ & 0.265 & 0.000 \\
\hline & High & $-3.64^{*}$ & 0.468 & 0.000 \\
\hline & Very High & $-8.56^{*}$ & 0.362 & 0.000 \\
\hline \multirow[t]{5}{*}{ High } & Poor & $15.10^{*}$ & 0.462 & 0.000 \\
\hline & Very Low & $12.00^{*}$ & 0.482 & 0.000 \\
\hline & Low & $7.39^{*}$ & 0.452 & 0.000 \\
\hline & Average & $3.64^{*}$ & 0.468 & 0.000 \\
\hline & Very High & $-4.92^{*}$ & 0.515 & 0.000 \\
\hline Very & Poor & $20.02^{*}$ & 0.353 & 0.000 \\
\hline \multirow[t]{4}{*}{ High } & Very Low & $16.92^{*}$ & 0.380 & 0.000 \\
\hline & Low & $12.31^{*}$ & 0.341 & 0.000 \\
\hline & Average & $8.56^{*}$ & 0.362 & 0.000 \\
\hline & High & $4.92^{*}$ & 0.515 & 0.000 \\
\hline
\end{tabular}

There was a strong correlation between household income and the number of hours of household access to water daily ( $\mathrm{r}$ $=0.7483 ; \mathrm{p}=0.001)$. The 0.006 rate of increase indicates that every additional income of ZMW 1000 to households in Kalingalinga Township increases their chances of access to water by 9.9 hours per day (Fig. 4). As such water access is highly linked to level of income.

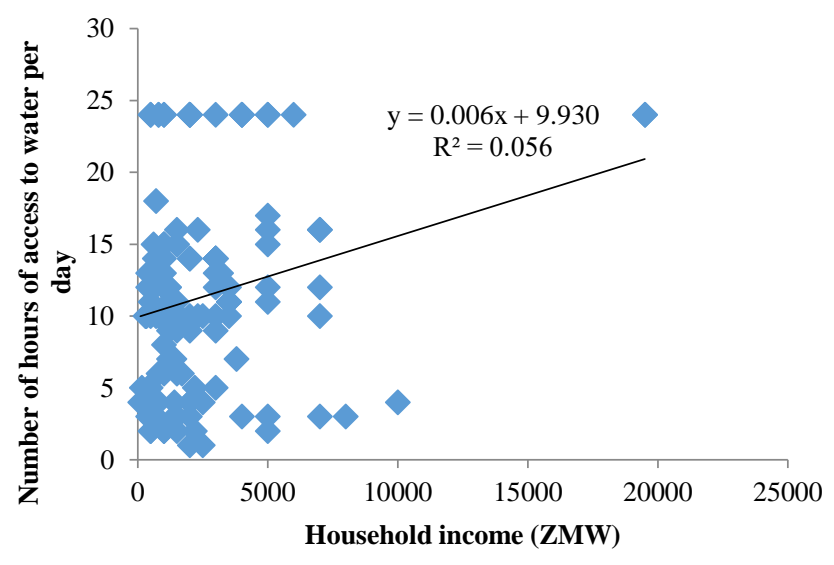

$\checkmark$ Number of hours of water access

Fig. 4. Scatter plot of levels of income among residents of Kalingalinga and the number of hours of water access.

The use of boreholes and shallow wells introduced the need for treating the water before domestic use. Majority of the residents $(65 \%)$ did not treat the water as they believed it was already clean as it was tap water. While boiling and chlorine application were also methods utilized by some residents, there was at least $8 \%$ who did not treat the water regardless of the source (Fig. 5).

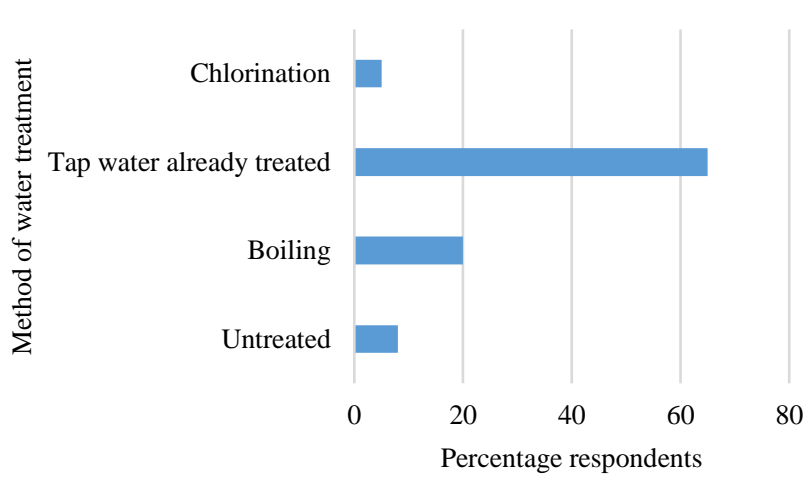

Fig. 5. Methods of water treatment among residents of Kalingalinga Township.

\section{Methods of Waste Disposal}

Residents of Kalingalinga Township rated poor waste disposal as a major sanitation challenge that was only second to poor drainage systems. The most common methods of waste disposal in the area were use the of informal waste collectors, which was utilized by nearly half the residents, while depending on the Lusaka City Council waste collectors and use of Bins were a distant second and third most preferred methods of waste disposal, respectively (Fig. 6).

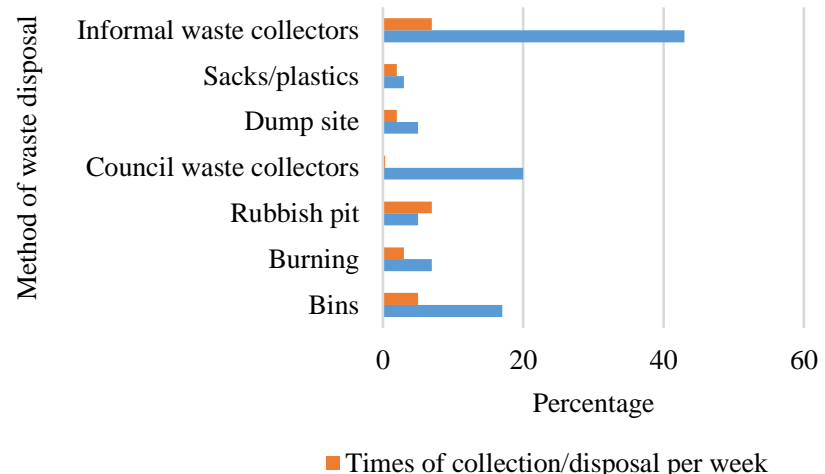

Fig. 6. Methods of waste disposal in Kalingalinga Township and the times of waste collection per week.

The use of rubbish pits and informal waste collectors were the most common methods of waste collection among households in Kalingalinga with a 7 day frequency of collection in a week. Lusaka City Council waste collectors were said to be the least available waste collectors being with a collection frequency of about 0.3 times per day or once every 3 weeks. Burning was also a relatively common method of waste disposal with residents admitting to practicing some sort of open air burning at least 3 times a week (Fig. 6).

In order to determine the residents' perceptions of the sanitation conditions in Kalingalinga, two variables were used as the basis for comparison; level of education of respondents (Table III) and period of stay in the area (Table IV). There was a significant difference in the ratings by different respondents based on their level of education $(\chi 2=$ 8.466; $p=0.748)$. This implied that the level of education of respondents affected their view of the sanitary conditions within the Township. 
TABLE III: CHI-SQUARE TEST FOR RATING OF SANITATION CONDITIONS IN KALINGALINGA TOWNSHIP BASED ON THE LEVEL OF EDUCATION BY RESIDENTS

\begin{tabular}{|c|c|c|c|c|c|c|c|}
\hline \multirow[t]{2}{*}{ Level of Education } & \multirow{2}{*}{$\begin{array}{c}\text { Observed and } \\
\text { Expected Counts }\end{array}$} & \multicolumn{5}{|c|}{$\begin{array}{c}\text { Rating of sanitation based on respondents' level of } \\
\text { education }\end{array}$} & \multirow[t]{2}{*}{ Total } \\
\hline & & Poor & Average & Good & Very Good & Excellent & \\
\hline \multirow{2}{*}{ Junior High } & Count & 6 & 3 & 11 & 9 & 6 & 35 \\
\hline & Expected Count & 6.4 & 4.2 & 9.7 & 6.9 & 7.8 & 35 \\
\hline \multirow{2}{*}{ Primary } & Count & 6 & 4 & 7 & 5 & 5 & 27 \\
\hline & Expected Count & 4.9 & 3.2 & 7.5 & 5.4 & 6 & 27 \\
\hline \multirow{2}{*}{ Senior High } & Count & 10 & 5 & 15 & 7 & 11 & 48 \\
\hline & Expected Count & 8.8 & 5.7 & 13.3 & 9.5 & 10.7 & 48 \\
\hline \multirow{2}{*}{ Tertiary } & Count & 1 & 3 & 2 & 4 & 6 & 16 \\
\hline & Expected Count & 2.9 & 1.9 & 4.4 & 3.2 & 3.6 & 16 \\
\hline \multirow{2}{*}{ Total } & Count & 23 & 15 & 35 & 25 & 28 & 126 \\
\hline & Expected Count & 23 & 15 & 35 & 25 & 28 & 126 \\
\hline Statistic & Value & df & p-value & & & & \\
\hline Pearson Chi-Square & 8.466 & 12 & 0.748 & & & & \\
\hline Likelihood Ratio & 8.9 & 12 & 0.711 & & & & \\
\hline
\end{tabular}

TABLE IV: CHI-SQUARE TEST FOR RATING OF SANITATION CONDITIONS IN KALINGALINGA TOWNSHIP BASED ON THE LENGTH OF STAY IN THE TOWNSHIP BY RESPONDENTS

\begin{tabular}{|c|c|c|c|c|c|c|c|}
\hline \multirow{2}{*}{$\begin{array}{c}\text { Length of stay in } \\
\text { Kalingalinga (Years) }\end{array}$} & \multirow{2}{*}{$\begin{array}{l}\text { Observed and Expected } \\
\text { Counts }\end{array}$} & \multicolumn{5}{|c|}{ Rating Sanitation from Length of Stay } & \multirow[t]{2}{*}{ Total } \\
\hline & & Poor & Average & Good & Very Good & Excellent & \\
\hline \multirow{2}{*}{$>2$} & Count & 5 & 1 & 3 & 4 & 1 & 14 \\
\hline & Expected Count & 2.3 & 2.6 & 3.8 & 2.3 & 3 & 14 \\
\hline \multirow{2}{*}{$03-10$} & Count & 2 & 7 & 11 & 3 & 2 & 25 \\
\hline & Expected Count & 4.1 & 4.7 & 6.8 & 4.1 & 5.4 & 25 \\
\hline \multirow{2}{*}{$11-20$} & Count & 3 & 7 & 7 & 1 & 7 & 25 \\
\hline & Expected Count & 4.1 & 4.7 & 6.8 & 4.1 & 5.4 & 25 \\
\hline \multirow{2}{*}{$21-30$} & Count & 7 & 5 & 2 & 2 & 7 & 23 \\
\hline & Expected Count & 3.7 & 4.4 & 6.2 & 3.7 & 5 & 23 \\
\hline \multirow{2}{*}{$31-40$} & Count & 0 & 1 & 5 & 4 & 5 & 15 \\
\hline & Expected Count & 2.4 & 2.8 & 4.1 & 2.4 & 3.2 & 15 \\
\hline \multirow{2}{*}{$41-50$} & Count & 0 & 0 & 1 & 2 & 2 & 5 \\
\hline & Expected Count & 0.8 & 0.9 & 1.4 & 0.8 & 1.1 & 5 \\
\hline \multirow{2}{*}{$>51$} & Count & 0 & 0 & 1 & 2 & 0 & 3 \\
\hline & Expected Count & 0.5 & 0.6 & 0.8 & 0.5 & 0.6 & 3 \\
\hline \multirow{2}{*}{ Total } & Count & 18 & 21 & 30 & 18 & 24 & 111 \\
\hline & Expected Count & 18 & 21 & 30 & 18 & 24 & 111 \\
\hline Statistic & Value & df & p-value & & & & \\
\hline Pearson Chi-Square & 47.757 & 28 & 0.011 & & & & \\
\hline Likelihood Ratio & 50.931 & 28 & 0.005 & & & & \\
\hline
\end{tabular}

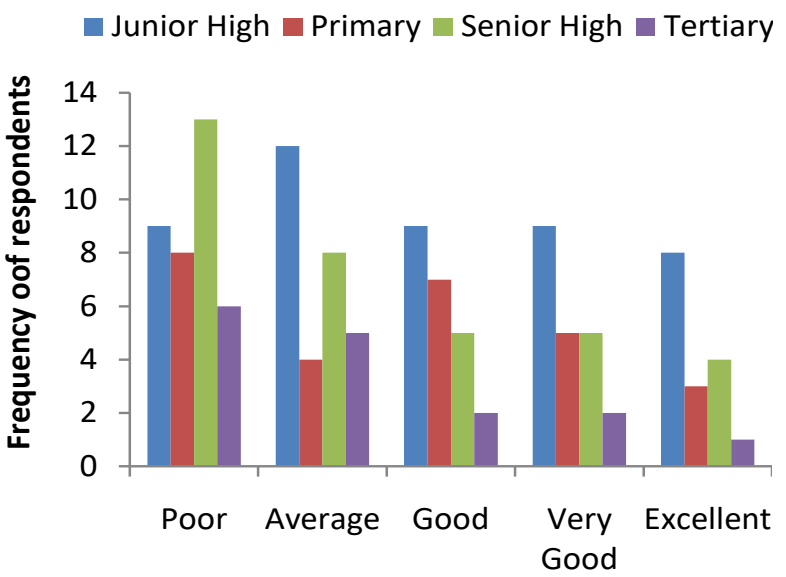

(a)
Residents ratings

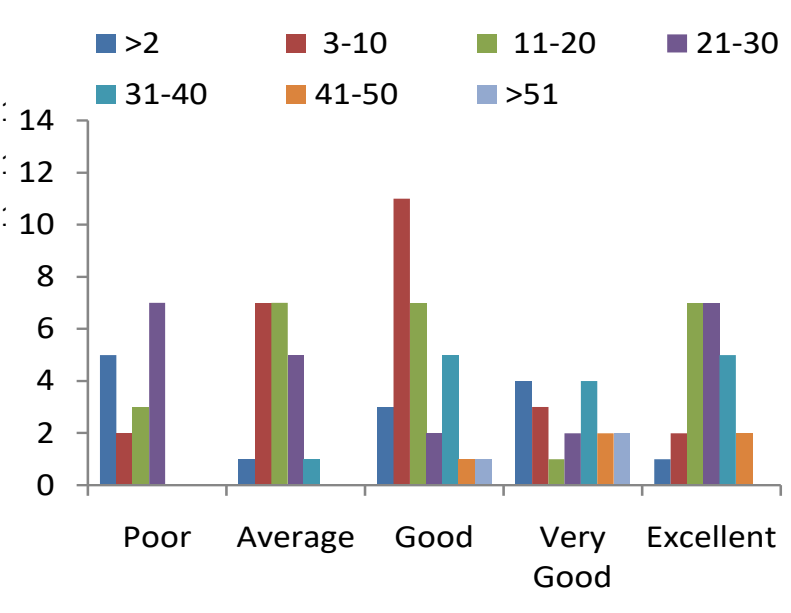

(b)

\section{Residents' ratings}

Fig. 7. Residents' rating of sanitation conditions in Kalingalinga based on their (a) level of education (b) length of stay in the Township.

The higher the level of education attained by residents, the lower the ratings they attributed to sanitation conditions in Kalingalinga Township. For example, most residents who had attained tertiary education were more stringent in their rating of sanitation conditions in Kalingalinga Township, with most of them rating the conditions as poor (Fig. 7a). Respondents who had only gone up to Junior High school where more likely to give the sanitation conditions a higher rating. However, the ratings of residents based on their length of stay in the township did not show significant differences (Fig. 7b).

The period of residents' stay in Kalingalinga Township did not significantly influence their rating of sanitation conditions in the township $(\chi 2=47.757 ; p=0.011)$. The level of education apparently had more effect on how residents perceived the sanitation conditions than did the length of stay of residents in the township. 


\section{DisCUSSION}

The sanitation challenges in Kalingalinga Township are highly interlinked. While respondents considered poor drainage systems as their major sanitary concern, the blocked drainages were mostly a result of poor waste disposal systems in the area. Informal waste collectors did not always disposeoff the waste at stipulated dumpsites, or at the Lusaka City Council waste bin but would dump the waste in drainages thereby blocking them. The blocked drainages could not efficiently allow the water passing through them, a situation that exacerbates flooding in the area. A combination of increased flooding and stagnant water is a catalyst for waterborne diseases such as cholera and could also provide breeding ground for mosquitoes leading to high incidences of malaria. Flooding is also a potential health hazard in situations where households use pit latrines and shallow wells for domestic water supply. Floods could result in the mixing of the contents of the pit latrines and water from shallow wells, potentially contributing to human sickness such as diarrhea which in children can cause malnutrition because nutrients will not be absorbed and retained in the body [16].

On the other hand, erratic water supply exacerbates unsanitary conditions. Flushable toilets which are the major form of toilets used in the area are highly dependent on a constant supply of water. Maintaining clean flushable toilets become a challenge when water is unavailable. With the majority of residents receiving less than 12 hours of access to water, the challenge of maintaining sanitary flushable toilets is extremely high.

Perceptions of residents towards sanitation in Kalingalinga Township were assessed through respondents' rating of the sanitary conditions that were observed. The perceptions highlighted that length of stay in a particular area does not influence the way residents perceive sanitation. However, education and exposure are able to shape residents' perceptions. For example, in this study most residents who had reached higher levels of education had a much lower rating of the sanitation conditions in Kalingalinga than did residents who had not gone far in formal education. This finding highlighted the importance of exposure to improved sanitation. The fact that respondents who had gone far in formal education have had a higher exposure to different sanitation conditions in different institutions could have made them to develop a more stringent rating system of their own sanitation conditions. Recognizing the sanitation shortfalls of residents in comparison to other institutions could prove to be a motivating factor in ensuring the residents improve on their own sanitation conditions. Further, a change in the attitude of residents towards waste management, use of designated solid waste collectors who take waste to designated dump sites, use of disinfectants in toilets and avoiding stagnating waste water would also help to manage sanitation in the area. Such a change is possible at all household levels of income.

The general lack of sustainable waste management practices in Kalingalinga Township was evident in the methods of waste disposal employed by residents. Use of informal waste collectors, packing waste in sacks, use of rubbish pits or burning were all unsustainable methods of waste management, as the waste found itself in the same environment instead of getting rid of it. Sustainable waste management in the area should start with the separation of the waste into different categories such as paper, bottles, organic waste, plastics and metal. The different waste categories could either be reused or recycled. Organic waste could be converted into compost which could be used in home gardens by residents for plant or vegetable production. Inorganic waste such as plastics and bottles could be sold to companies which can be recycled and be used to manufacture make finished goods. However, for this improved solid waste management system to be effective, residents will need to be sensitized and exposed to such waste management techniques. Residents should learn the skill of separating wastes into usable categories which they can further sell to earn an income. Further, there is need for companies which utilize such waste materials to set up depot in easily accessible areas close to the township.

\section{CONCLUSION}

Most of the waste management strategies practiced by residents of Kalingalinga Township were unsustainable. Many of them depended on informal waste collection and sometimes disposed-off the waste in drainages, contributing to blockages and eventual flooding, or utilized rubbish pits or sacks and plastics. Most of the waste disposed-off in this way did not reach the stipulated Lusaka City Council dumpsites and ended up back in the township environment creating unsanitary conditions in the area. The sanitation challenges could have been exacerbated by the erratic water supply in the township which had a direct relationship with levels of household income. However, exposure through education also contributed to residents' perceptions of the sanitary conditions in the area. Exposure could be a catalyst towards improved sanitary conditions as residents would emulate the sanitary conditions observed in other institutions which could drive them towards improving their own sanitation in their households. The study proposed participant education of residents in the art of separating waste into different recyclable or reusable categories for purposes of household reuse in the case of organic waste or selling-off to industries which utilize non-biodegradable waste as raw materials. Sanitation management also entails that residents become aware of and have easy access to industries which are in need of particular waste as inputs in their manufacturing processes.

While level of income was a determinant to access to water supply in the Township, the residents' poor attitude towards solid waste disposal was a major challenge contributing to unsanitary conditions in the area. The study identified the need to separate generated waste into usable categories that could be recycled, reused, and sold as raw materials to particular manufacturing industries. The success of locally driven options would hinge on residents being educated on the sustainable waste management techniques which would also contribute to household income generation through selling off usable wastes. While the Lusaka City Council was often mentioned as a major solution towards waste management in the area, the study recommended participatory education of the locals in sustainable waste management, conversion of household waste into household income and a change in residents' attitude as the starting point in ensuring successful sanitation management. The successful sanitation management also entails that all 
residents especially children in the bracket of the critical period of 1000 days will be healthy because nutrients will be absorbed and retained in their bodies.

\section{CONFLICT OF INTEREST}

We declare that we do not have any conflict of interest.

\section{REFERENCES}

[1] WHO. The Sanitation Challenge: Turning Commitment into Reality. WHO, Geneva. 2004.

[2] Musonda-Mubanga A, Chakanika WW, Mubanga K.H. Sanitation and Hygiene in Public Boarding Schools in Chongwe Zambia: What do pupils know? Do they care? Chalimbana University Multi-Disciplinary Journal of Research, 2019: 1(1): 1-11.

[3] Minh VH, Hung VM. Economic Aspects of Sanitation in Developing Countries. Environmental Health Insights, 2011: 5: 63-70.

[4] Ministry of Local Government and Housing. National Urban Water Supply and Sanitation Programme 2009-2030 Background and Analysis. MLGH, Lusaka. 2008.

[5] WSUP. Zambia-Improving water supply and waste collection services. Water and Sanitation for the Urban Poor. 2018.

[6] Mweemba C. Assessment of the Performance of the Water Supply and Sanitation Service Provision in Lusaka District, 2006 - 2011. MSc. Dissertation. The University of Zambia, Lusaka. 2013.

[7] Renouf R. Towards City-Wide Sanitation in Lusaka: the next phase of non-sewered sanitation. Water and Sanitation for the Urban Poor, Lusaka. 2018.

[8] Dewey KG, Adu-afarwuah S. Systematic review of the efficacy and effectiveness of complementary feeding interventions in developing countries. Maternal \& Child Nutrition, 2008: 4, 24-85.

[9] Tidwell JB, Chipungu J, Bosomprah S, Aunger R, Curtis V, Chilengi R. Effects of a Behaviour Change Intervention on the Quality of PeriUrban Sanitation in Lusaka, Zambia: a randomized controlled trial. Lancet Planet Health, 2019: 3:187-96.

[10] Anderson A. Nutrition and Food Science. McGraw-Hill Book Company. New York; 2008.

[11] Esrey SA. Water, waste, and well-being: a Multi-country study. American Journal of Epidemiology, 1996: 143, 608-623.

[12] Black RE, Allen LH, Bhutta ZA, Caulfield LE, De onis M, Ezzati M, Mathers C, Rivera J. Maternal and child undernutrition: global and regional exposures and health consequences. The Lancet, 2008: 371, 243-260.

[13] Ministry of Local Government and Housing. National Rural Water Supply and Sanitation Programme 2006-2015. MLGH, Lusaka. 2005.

[14] UNICEF. Impact Evaluation of the Sanitation and Hygiene Program in Zambia. UNICEF, Lusaka. 2017.

[15] Shalabh S, Schomaker M, Heumann C. Introduction to Statistics and Data Analysis. Springer. Kanpur.2016.

[16] Briend A. Is diarrhoea a major cause of malnutrition among the underfives in developing countries? A review of available evidence. European Journal of Clinical Nutrition, 1990: 44, 611-628. 